\title{
GABAergic signaling by cells of the immune system: more the rule than the exception
}

\author{
Amol K. Bhandage ${ }^{1} \cdot$ Antonio Barragan ${ }^{1}$ (i)
}

Received: 22 March 2021 / Revised: 17 May 2021 / Accepted: 11 June 2021 / Published online: 21 June 2021

(c) The Author(s) 2021

\begin{abstract}
Gamma-aminobutyric acid (GABA) is best known as an essential neurotransmitter in the evolved central nervous system (CNS) of vertebrates. However, GABA antedates the development of the CNS as a bioactive molecule in metabolism and stress-coupled responses of prokaryotes, invertebrates and plants. Here, we focus on the emerging findings of GABA signaling in the mammalian immune system. Recent reports show that mononuclear phagocytes and lymphocytes, for instance dendritic cells, microglia, T cells and NK cells, express a GABAergic signaling machinery. Mounting evidence shows that GABA receptor signaling impacts central immune functions, such as cell migration, cytokine secretion, immune cell activation and cytotoxic responses. Furthermore, the GABAergic signaling machinery of leukocytes is implicated in responses to microbial infection and is co-opted by protozoan parasites for colonization of the host. Peripheral GABA signaling is also implicated in inflammatory conditions and diseases, such as type 1 diabetes, rheumatoid arthritis and cancer cell metastasis. Adding to its role in neurotransmission, growing evidence shows that the non-proteinogenic amino acid GABA acts as an intercellular signaling molecule in the immune system and, as an interspecies signaling molecule in host-microbe interactions. Altogether, the data raise the assumption of conserved GABA signaling in a broad range of mammalian cells and diversification of function in the immune system.
\end{abstract}

Keywords Neurotransmission $\cdot$ Inflammation $\cdot$ Macrophage $\cdot$ Toxoplasma $\cdot$ Apicomplexa $\cdot$ Host-pathogen $\cdot$ Voltagedependent calcium channel $\cdot$ Cation-chloride cotransporter

\section{Introduction}

Gamma-aminobutyric acid (GABA) was first identified in 1949 as a plant metabolite [1] and, shortly after (1950), it was reported in the vertebrate brain [2]. Today, GABA has an undisputed role as the principal inhibitory neurotransmitter in the central nervous system (CNS) of vertebrates [3]. Yet, GABA has also metabolic and signaling functions in prokaryotic and eukaryotic microorganisms, and in invertebrates [4]. It is also well established that GABA has functions in the peripheral nervous system [5, 6]. More recently, GABA has been found in pancreatic islets [7] and peripheral GABAergic signaling has been implicated in cancer and other inflammatory conditions in humans [8-11].

Antonio Barragan

Antonio.barragan@su.se

1 Department of Molecular Biosciences, The Wenner-Gren Institute, Stockholm University, Stockholm, Sweden
Neurons and other GABAergic cells synthesize GABA via glutamate decarboxylases (GAD65/67) and transamination (GABA-T) catabolizes GABA [12]. GABA is released from cells by exocytosis or shuttled in and out of cells via GABA transporters (GATs) [13]. Upon extracellular release, GABA can activate GABA-A receptors (GABA-A Rs) [14] and GABA-B Rs [15] located in the cell membrane. GABA$B$ receptors are metabotropic G-protein-coupled receptors, while GABA-A Rs are pentameric ionotropic chloride channels, normally comprised of three types of subunits: $2 \alpha$ 's, $2 \beta$ 's, and a third type of subunit. By combining the 19 different mammalian GABA-A R subunits $(\alpha 1-6, \beta 1-3, \gamma 1-3$, $\delta, \varepsilon, \pi, \theta$ and $\rho 1-3)$, numerous variants of heteropentameric receptors can form in neuronal cells. Additionally, the $\rho$ subunits can form homopentameric channels [16].

The strength and polarity of GABA signaling by GABAA Rs is modulated by cation-chloride cotransporters (CCCs), that regulate intracellular chloride $\left(\mathrm{Cl}^{-}\right)$concentrations among other functions [17]. CCCs maintain the $\mathrm{Cl}^{-}$gradient to favor outward $\mathrm{Cl}^{-}$flux (Na-K-Cl cotransporters, NKCCs) 
or inward $\mathrm{Cl}^{-}$flux ( $\mathrm{K}-\mathrm{Cl}$ cotransporters, $\mathrm{KCCs}$ ). GABA-A R activation by GABA can elicit opening of voltage-dependent calcium $\left(\mathrm{Ca}^{2+}\right)$ channels (VDCCs) with subsequent calcium $\mathrm{Ca}^{2+}$ influx into the neuronal cell [18]. GABA-A Rs have a broad range of sensitivity. Synaptic receptors are activated by millimolar concentrations of GABA, whereas extra-synaptic or non-synaptic receptors can be activated by GABA concentrations in the picomolar range [19-21]. In peripheral tissues and blood, sub-micromolar GABA concentrations have been measured [22-24].

In vertebrates, immune cells derive from common progenitor stem cells in the bone marrow, which generate myeloid lineages [monocytes, dendritic cells (DCs), macrophages, granulocytes], or lymphoid lineages [B, T, natural killer (NK) cells] [25]. These cells mediate the complex responses that entail combating infections, cancer and tissue injury. The first line of defense is the innate response which is immediate. The second line of defense is the adaptive immune response which is generally highly specific and long-lasting. Naturally, the orchestration of innate and adaptive immune responses requires a tight regulation within the immune system and entail ever-broadening signaling cascades [26]. Mounting evidences show that immune cells can respond to neurotransmitters, for example acetylcholine [27], and signaling molecules present in the CNS are emerging as modulators of immune function [28]. Here, we outline recent findings on the role of GABA signaling in immune cells and discuss its impact on the effector functions of immune cells and disease.

\section{GABAergic signaling in mononuclear phagocytes}

The mononuclear phagocyte system comprises DCs, monocytes, macrophages and brain microglia, among others [29]. Mononuclear phagocytes have diverse immunological functions and are crucial to counteract microbial infection. As sensors and effector cells in peripheral tissues, phagocytes participate in phagocytosis, cytokine responses and antigenic presentation for initiation of adaptive immune responses. The trafficking of phagocytes in response to external cues, for example invasive pathogens, is complex and the molecular signaling that regulates migration has not been fully elucidated [30]. Chemokine signaling cues guide afferent responses to inflammation sites and efferent responses, for example migration of DCs to lymph nodes where adaptive immune responses are initiated [31]. To avoid clearance by the immune response, pathogens have evolved diverse strategies to subvert this fundamental function of DCs and other mononuclear phagocytes [32, 33]. Paradoxically, these fundamental host-protective immune responses also constitute a gate for immune evasion and dissemination by pathogens.

\section{GABAergic signaling components expressed by mononuclear phagocytes}

A comprehensive characterization of myeloid mononuclear phagocytes of human and mouse origin recently demonstrated a conserved expression of GABAergic molecular components [34]. Phagocytes consistently expressed the five principal components of GABAergic signaling (Fig. 1), namely (i) GABA metabolism, (ii) GABA transportation and secretion, (iii) GABA-A R activation, (iv) GABA signaling regulation by CCCs, and (v) effector $\mathrm{Ca}^{2+}$ channel signaling by VDCCs (Table 1). Furthermore, in both human and murine DCs, GABA evoked GABA-A R-mediated currents [35], with characteristics of neuronal synaptic and extra-synaptic GABA-activated currents [21].

In phagocytes, GAD67 was identified as the principal GABA synthesizing enzyme, while the relative expression of GAD65 was low in murine cells and undetectable in human cells [34]. Upon infection challenge with coccidian parasites, the extracellular GABA concentrations raised dramatically. Together with GAD67 expression, this is indicative of cytosolic GABA synthesis and vesicleindependent secretion by transportation through GATs, in line with secretory pathways described in neurons $[57,58]$. Nonetheless, the precise secretory pathways of GABA in phagocytes remain uncharacterized.

The expression of GABA-A R subunit types was diverse in phagocytes, in line with the expression diversity in neurons $[59,60]$. Yet, the repertoires of GABA-A $\mathrm{R}$ subunits expressed by different phagocyte types were, in theory, sufficient to constitute functional channels: at least one $\alpha$, one $\beta$, and one-third type of subunit, or homopentamer-forming $\rho$ subunits. While the precise subunit constituents of pentameric GABA-A Rs in phagocytes remain unknown, a functional hierarchy among GABAA R subunits was identified and is discussed below [34]. Importantly, phagocytes expressed CCCs, which regulate GABA-A R function. Specifically, expression of NKCC1 was linked to GABA-A R function in DCs.

Finally, phagocytes expressed a highly conserved repertoire of VDCC sub-types. Stimulation of DCs with GABA elicited $\mathrm{Ca}^{2+}$ influx transients in the cytosol, which was inhibited by GABA-R antagonism. A prominent role for the VDCC subtype $\mathrm{Ca}_{\mathrm{V}} 1.3$ was demonstrated in human and murine cells $[34,36]$. Thus, both human and murine phagocytes express a fully functional GABAergic machinery. 

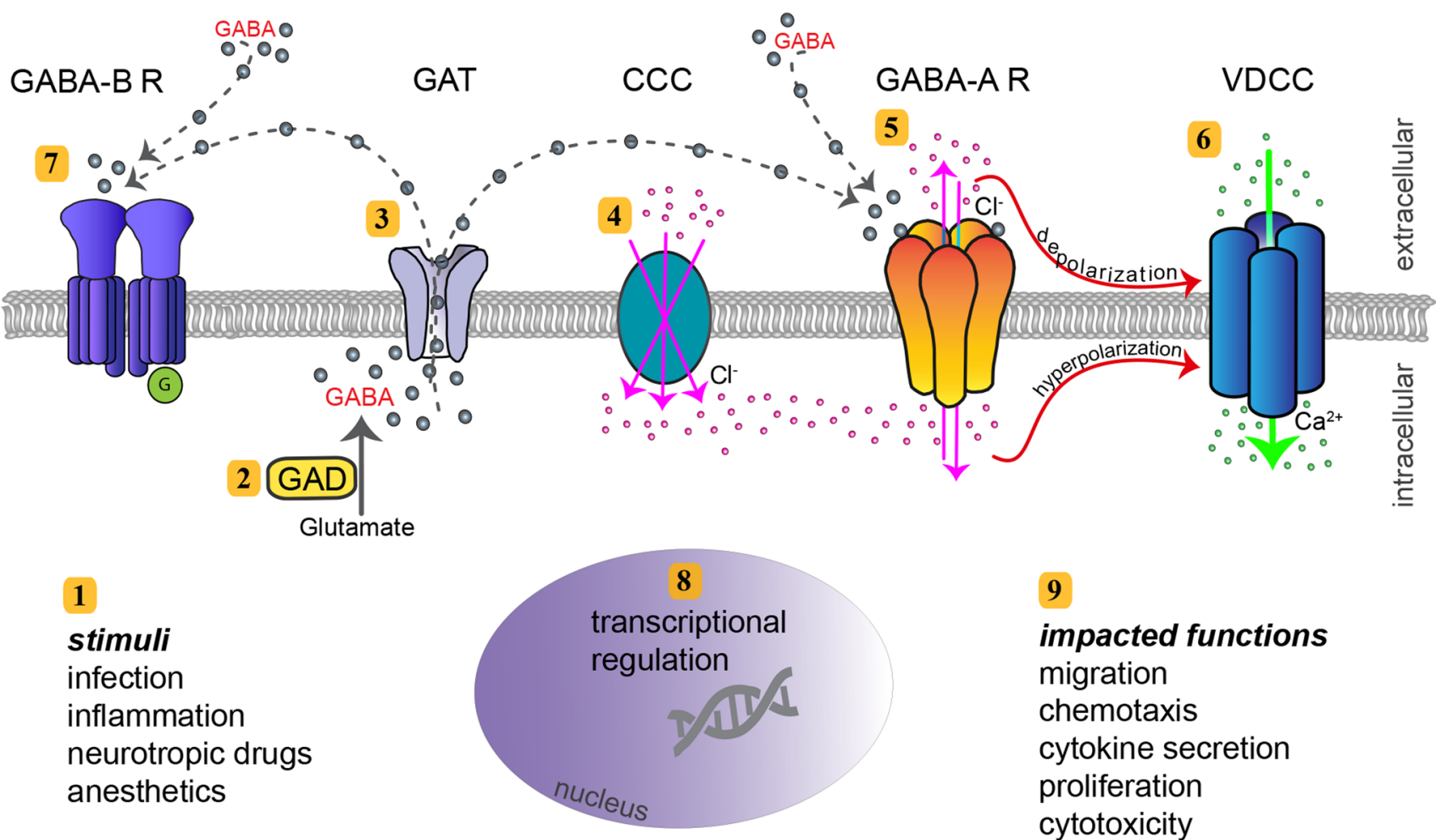

Fig. 1 Molecular GABA signaling components, and immune cell functions linked to GABAergic signaling. The cartoon depicts the intracellular and extracellular compartments of a leukocyte, separated by the lipid bilayer of the cytoplasmatic membrane. 1 Extracellular/exogenous stimuli and intracellular/endogenous stimuli impact GABA signaling in leukocytes and exert paracrine and endocrine effects, respectively. 2 In GABAergic immune cells, GABA is enzymatically synthesized by glutamate decarboxylase (GAD65/67). 3 GABA transporters (GAT) transport GABA out from leukocytes. It remains undetermined if GAT transport also mediates influx of GABA in leukocytes, as in neurons. 4 Cation-chloride $\left(\mathrm{Cl}^{-}\right)$transporters (CCC) include expression of members from the KCCC and NKCC families. By maintaining $\mathrm{Cl}^{-}$homeostasis and ionic gradient, they can function as regulators of GABA signaling. NKCCs mediate coupled movement of $\mathrm{Cl}^{-}$, sodium $\left(\mathrm{Na}^{2+}\right)$ and potassium $\left(\mathrm{K}^{+}\right)$into the cytosol across the plasma membrane (illustrated), while KCCs

\section{Motogenic effects of GABAergic signaling in phagocytes}

Activation of the GABAergic system of phagocytes by challenge with coccidian parasites mediates activation of motility in vitro and migratory responses in vivo in mice. This migratory activation is termed hypermigratory phenotype [61, 62]. Selective pharmacological antagonism of GABA-A R subunits indicates implication of $\alpha, \beta$ and $\rho$ subunits in migratory responses. Additionally, in human or murine DCs, the finding that gene silencing of specific subunits $(\alpha 4, \beta 3$ and $\rho)$ inhibit GABA-A R-mediated hypermotility, but not gene silencing of $\alpha 3$ and $\rho 2$, indicates a hierarchy among GABA-A R subunits mediating mediate outward movement of $\mathrm{Cl}^{-}$and $\mathrm{K}^{+}$(not illustrated). 5 GABAA receptors (GABA-A R) are activated by GABA and efflux or influx of $\mathrm{Cl}^{-}$takes place, depending on the intracellular $\mathrm{Cl}^{-}$concentration maintained by CCCs. 6 GABA-A R activation can result in depolarization of the membrane, leading to calcium $\left(\mathrm{Ca}^{2+}\right)$ entry into the cell by opening of voltage-dependent $\mathrm{Ca}^{2+}$ channels (VDCC). If GABAA R activation results in hyperpolarization, VDCCs are inactivated. Influx of the second messenger $\mathrm{Ca}^{2+}$ can impact multiple signaling pathways and cellular functions. 7 GABA-B receptors (GABA-B R) are metabotropic G-coupled receptors activated by GABA. 8 In a number of leukocytes, there is evidence of considerable transcriptional regulation and modulation of GABAergic genes and GABArelated genes, which will determine elevated or reduced protein expression. 9 Immune cell effector functions affected by GABAergic signaling

migratory activation or redundancy of function between subunits [34]. Similarly, pharmacological antagonism and gene silencing of NKCC1 or the VDCC subtype $\mathrm{Ca}_{\mathrm{V}} 1.3$ impacted the migration of DCs in vitro and in vivo in mice $[34,36]$. This underlines the importance of the sequential GABAergic signaling cascade for the migratory activation of phagocytes.

It is tempting to draw parallels between the migratory effects of GABA on phagocytes and the motogenic role of GABA in embryonic interneuron migration in the developing fetus [18]. Furthermore, GABA-A R signaling has newly been associated with cancer cell metastasis, for example pancreatic cancer and breast cancer [63, 64]. Future research needs to determine if the motogenic molecular 


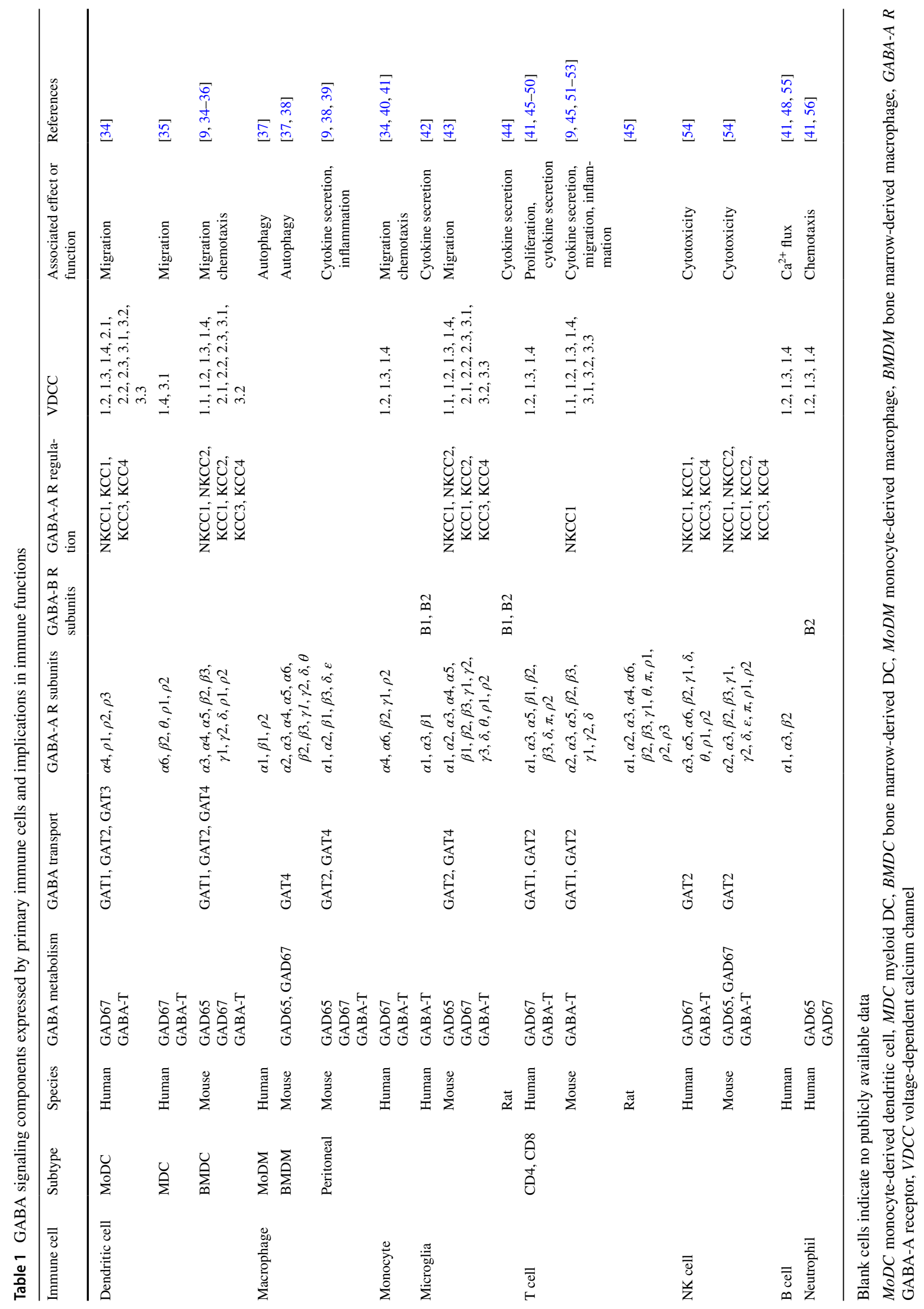


components identified in phagocytes $[34,36]$ are also implicated in immunomodulation and in cancer cell metastasis. Thus, receptor sub-types or other GABAergic components may be targeted to modulate cellular processes of clinical relevance [65].

\section{Motogenic GABAergic signaling and chemotaxis: synergistic effects?}

Upon GABAergic activation, DCs maintain their chemotactic responses mediated by chemokine receptor 7 (CCR7) and in response to the chemokines CCL19/21 [35, 66]. Interestingly, upon GABAergic inhibition, DCs responded with directionality in the chemokine gradient but at significantly reduced velocities of DCs, thereby reducing the overall chemotactic response. This indicates that GABAergic activation DCs primarily acts on the mechanisms of cell motility rather than on regulation of directionality [67, 68]. Thus, GABA/GABA-A R-mediated hypermotility and CCR7-mediated chemotaxis acted simultaneously and enhanced the migratory properties of DCs [35, 62]. Similarly, chemokinetic GABAergic signaling cooperated with other chemotactic cues for embryonic neuronal migration [69]. In other cellular systems, GABAergic inhibition reduced the chemotaxis of monocytes and neutrophils [40, 56]. Moreover, GABA-B R signaling has been implicated in cancer cell metastasis [70] and in the motility of human sperm cells [71]. It remains unknown if GABA can also act as a chemoattractant for homing of phagocytes.

\section{Role of GABAergic signaling in immune activation of phagocytes}

Immunomodulatory and down-modulatory effects by GABA were described early in peripheral blood mononuclear cells [48] and in experimental autoimmune encephalomyelitis, a model for multiple sclerosis [9]. Furthermore, GABA modulated cytokine release by peripheral blood mononuclear cells [50]. Specifically, GABA treatment has been reported to reduce IL-6/IL-12 production in macrophages [39] and impaired phagocytosis of macrophages and monocytic cells $[40,72]$. However, the GABA transporter GAT2 was recently linked to pro-inflammatory IL- $1 \beta$ secretion in peritoneal macrophages [38]. A recent study showed that activation or blockade of GABA-A Rs influenced the phenotypic characteristics of alveolar macrophages towards classical (M1) or alternative (M2) activation, respectively [73]. Moreover, GABA signaling has been associated with antimicrobial responses, activation of autophagy, and phagosomal activation in macrophages challenged with intracellular bacteria [37]. Thus, upcoming evidences indicate that parasites, bacteria, and viruses modulate GABAergic signaling in immune cells for survival [35, 37, 74].

Jointly, GABA has been attributed both inhibitory effects on phagocyte activation and pro-inflammatory functions. This is likely a reflection of the versatility of GABAergic signaling and that its effects may be contextual and related to specific types/sub-types of phagocytes or their activation state. Yet, the understanding of how GABA impacts different immune functions is partly hampered by limited knowledge on the expression of GABA receptor subsets in different phagocytes and how these are implicated in cell type-specific effector functions. It remains also unknown if activation occurs in response to ambient GABA gradients in physiological compartments or if secreted GABA by an autocrine or paracrine loop is required for receptor activation. In these settings, the identification of novel extra-synaptic GABA-A/B R modulators may prove useful to test the impact of GABA signaling on immune cell functions and inflammation [75-77]. One interesting perspective is also the acidifying action of GABA-A Rs on intracellular pH [78]. Because intracellular pH gradients can influence the migration of cells [79], the activation of the inflammasome, and cytokine secretion [80], this merits further investigation.

\section{Microglia}

Microglia are, in fact, part of the mononuclear phagocyte system [29] and are discussed separately here based on their specialized functions in the CNS. Microglial cells originate from primitive hematopoietic precursors outside the CNS and become the resident phagocytes of the brain [81]. Microglia participate in immune surveillance by rapidly responding to tissue injury and inflammation, similar to macrophages in peripheral tissues [82]. In neuroinflammatory processes, microglia also mediate regulative interactions with the endothelium of the neurovascular unit [83]. Additionally, microglia are important for neuroplasticity processes, for example in structural modifications after ischemic and traumatic insults $[84,85]$.

\section{Microglia express a GABAergic machinery}

Earlier studies showed that microglia can respond to GABA and GABA-A R modulators with electrophysiological currents [86]. Moreover, expression of GABA-B Rs was reported in activated rat microglia [44] and expression of GABA-T and 3 GABA-A R subunits $(\alpha 1, \alpha 3$, and $\beta 1$ ) in human microglia [42]. A recent comprehensive 
characterization in murine primary microglia revealed the expression of a complete GABAergic machinery (Table 1).

\section{Functions linked to GABAergic signaling in microglia}

Importantly, microglia secreted GABA and exhibited migratory activation upon infection challenge [43]. Thus, infectious challenge with Toxoplasma gondii activated migration of microglia though GABAergic signaling, similar to DCs. This reinforces the idea of a conserved motogenic GABAergic signaling machinery in phagocytes [34]. It also highlights a hypothetical interplay between microglia and leukocytes, which infiltrate the brain parenchyma during infection and inflammation [87]. Furthermore, these findings raise questions related to the alteration of GABAergic synapse signaling in the rodent brain upon $T$. gondii infection [88]. Moreover, GABA can suppress IFN- $\gamma$ production of microglia through inhibition of inflammatory pathways mediated by NF-kB and $\mathrm{p} 38$ mitogen-activated protein (MAP) kinases [42]. Because GABA-A R signaling impacts MAP kinase signaling via VDCCs in DCs [68] and migratory responses in microglia were linked to the MAPK regulator 14-3-3 [89], it is plausible that MAPK signaling is key to the modulatory effects of GABA on microglia. Finally, GABA signaling negatively regulated the dendritic morphology of mouse retinal microglia, indicating an impact on the cytoskeleton [90] and in line with the ascribed motogenic effects of GABA [34].

\section{T cells}

T lymphocytes mediate important adaptive immune responses and provide long-lasting immunity (memory $\mathrm{T}$ cells). As effectors of adaptive immunity, different subsets of $\mathrm{T}$ cells have crucial functions in cytotoxic responses $\left(\mathrm{CD} 8^{+}\right.$ $\mathrm{T}$ cells), regulatory responses $\left(\mathrm{CD} 4^{+}\right.$helper $\mathrm{T}$ cells), and cytokine responses against infection and cancer [91].

\section{GABAergic signaling components expressed by $T$ cells}

T cells harbor GAD67, GAT1, GAT2, GABA-T, and GABAA receptor subunits suggesting the presence of a GABAergic signaling system similar to the neuronal system. Similar to human mononuclear phagocytes and NK cells, human T cells have conserved the expression of GAD67, but not GAD65 (Fig. 1). The GABA-catabolizing enzyme, GABA-T, and GABA transporters, GAT1 and GAT2, are expressed by both murine and human T cells (Table 1). Whether GABA is synthesized cytosolically and secreted by transporters or packaged into vesicles for secretion remains undetermined. The reported expression of GABA-A R subunits and GABA synthesis enzymes varies between species and depends on cell activation status or experimental mode, and what drives this variation remains undefined [92]. For instance, as different T-cell subsets express different GABA-A R subunits, they may display different sub-types of GABA-A Rs with diverse pharmacological properties and effects [93, 94]. The strength and polarity of GABA-A R-activated chloride currents depend on the intracellular chloride concentration set by CCCs [17]. In murine T cells, only NKCC1 has been detected to date, but in human PBMCs (T cells constitute $45-70 \%$ of PBMCs), NKCC1, KCC1, KCC $3, \mathrm{KCC} 4$ were detected $[52,95,96]$. One single subunit of GABA-B Rs (B1) was detected in human PBMCs and it remains enigmatic if functional GABA-B R homodimers can be formed in $\mathrm{T}$ cells [95].

\section{Roles of GABAergic signaling in T cells}

GABA has been shown to suppress the proliferation of $\mathrm{T}$ cells and to inhibit immune responses through functional GABA receptors [50, 97, 98]. GABA-induced single channel and whole cell currents recorded with patch-clamp electrophysiology were abolished by GABA-A R antagonists indicating presence of functional GABA-A Rs in $\mathrm{CD} 4^{+} \mathrm{T}$ cells $[50,99]$. GABA inhibited $\mathrm{Ca}^{2+}$ influx and transcriptional activity of NF- $\mathrm{KB}$ in anti-CD3-stimulated human PBMCs and mouse splenic $T$ cells in a GABA-A R-dependent manner $[48,98]$. GABA and diazepam, a positive allosteric modulator of GABA-A Rs, inhibited IFN- $\gamma$ production in anti-CD3 stimulated human and murine $\mathrm{CD} 4^{+}$and $\mathrm{CD} 8^{+}$ $\mathrm{T}$ cells $[100,101]$. When the gene coding for NKCC1, a GABAergic signaling regulator, was silenced, ablated, or pharmacologically antagonized, the migration and chemotaxis of murine T cells was inhibited [52].

Furthermore, GABA inhibited the proliferation T cells, and directly or indirectly impacted the secretion of up to 47 different cytokines from PBMCs derived from type 1 diabetes patients [50]. In mice, the onset of type 1 diabetes was delayed presumably by a reduction of T-cell responses, which improved the survival of pancreatic $\beta$ cells [98, 101-103]. In a murine autoimmune encephalomyelitis (EAE) model, the GABA levels in serum and expression of GABA signaling components GAD, GAT1, GABA-T, and GABA-A receptor subunits in splenic $T$ cells were downmodulated [51, 104]. Additionally, GAT1 knock-out mice exhibited aggravated EAE, enhanced splenocyte proliferation, and inflammatory cytokine production, suggesting dysregulation of GABAergic signaling in multiple sclerosis [51]. GABA also impacted T-cell responses in rheumatoid arthritis [105] and psoriasis [106]. 


\section{VDCC components and functions in T cells}

Only L-type VDCCs have been detected in human T cells to date, whereas in murine $\mathrm{T}$ cells, both L-type and T type VDCCs were described (Table 1). However, human PBMCs expressed transcripts for all sub-types of VDCCs [107]. The VDCC subtype $\mathrm{Ca}_{\mathrm{V}} 1.4$ contributed in T-cell receptor (TCR) activation, in the development and survival of naïve $\mathrm{T}$ cells and knocking out $\mathrm{Ca}_{\mathrm{V}} 1.4$ or blocking L-type channels inhibited TCR-induced $\mathrm{Ca}^{2+}$ influx, IL-2 production and proliferation of $\mathrm{T}$ cells [108-110]. $\mathrm{Ca}_{\mathrm{V}} 1.1$ channels were also shown to contribute in TCR-induced $\mathrm{Ca}^{2+}$ influx [111, 112]. Among the $T$ helper cell sub-types, specifically murine Th2 cells, but not Th1 cells, expressed $\mathrm{Ca}_{\mathrm{V}} 1.2$ and $\mathrm{Ca}_{\mathrm{V}} 1.3$ channels. In a murine model of asthma, gene silencing of L-type VDCCs led to inhibition of TCR-induced signaling and cytokine secretion by $\mathrm{Th} 2$ cells, resulting in reduced inflammation and hyperactivity in lungs $[41,113]$. In murine $\mathrm{CD}^{+} \mathrm{T}$ cells, $\mathrm{Ca}_{\mathrm{V}} 3.1$ channels were functionally active at resting membrane potential and drove Th17 cell cytokine responses but did not contribute in TCR-induced or storeoperated $\mathrm{Ca}^{2+}$ entry (SOCE) [114].

Taken together, the data indicate that $\mathrm{T}$ cells harbor yet unidentified components of GABAergic and $\mathrm{Ca}^{2+}$ signaling machineries which regulate cellular functions such as proliferation, cytokine production, anti-inflammatory responses and $\mathrm{Ca}^{2+}$ homeostasis of $\mathrm{T}$ cells. In this context, the putative roles of store-operated $\mathrm{Ca}^{2+}$ (SOC) channels and other ion channels, for example potassium channels, need to be addressed due to their implication in various T-cell functions, including T-cell activation [115]. Because GABA-A R activation in $\mathrm{T}$ cells and other immune cells leads to changes in cell membrane potential, this may impact the function of SOC and potassium channels. Additionally, cross-regulation between VDCCs and SOCE may take place [116, 117]. Interestingly, GABA inhibits $\mathrm{Ca}^{2+}$ influx in T cells [98, 102], while GABA induces $\mathrm{Ca}^{2+}$ influx in phagocytes/DCs $[34,36]$. These, seemingly contraposed effects of GABA, may hypothetically be explained by depolarization-mediated inhibition of SOCE in T cells and depolarization-mediated opening of VDCCs in phagocytes, as suggested in neurons [118]. In line with this assumption, artificial depolarization with $\mathrm{KCl}$ led to $\mathrm{Ca}^{2+}$ influx in DCs but not in T cells [36, $119,120]$. Alternatively, the relative expression of NKCCs and KCCs may differ in these two cell types, thereby regulating the depolarizing or hyperpolarizing action of GABA-A Rs, as shown in interneurons [18]. Jointly, the $\mathrm{Ca}^{2+}$-related immunomodulatory effects of GABA on T cells and other immune cells need to be further explored.

\section{NK cells}

NK cells are effector lymphocytes of the innate immune system that mediate important responses against tumors and microbial infections [121]. NK cells have cytotoxic effects on target cells through perforin-dependent mechanisms or by inducing death receptor-mediated apoptosis. They also secrete cytokines that are pivotal for immunomodulation and are implicated in the regulation of T-cell-mediated responses. However, GABAergic signaling in NK cells has until recently remained unexplored [92].

\section{Expression of GABAergic signaling components by NK cells}

A recent report established that both human and mouse NK cells synthesize and secrete GABA, and express a GABAergic signaling machinery [54]. This includes GABA synthesis and degradation enzymes, GABA transporters, GABA-A R subunits, and CCCs, which can regulate GABA signaling (Table 1). Moreover, both human and mouse NK cells transcriptionally expressed repertoires of GABA-A R sufficient for the formation of heteropentameric $(2 \alpha: \mathrm{s}+2 \beta: \mathrm{s}+1$ additional subunit) and homopentameric ( $\rho: \mathrm{s})$ GABA-A Rs. The $\alpha 3, \beta 2$, and $\rho 2$ subunits were most commonly expressed by tested human donors. NKCC1 was the principal CCC expressed and thus putatively implicated in the regulation of the direction of $\mathrm{Cl}^{-}$flux mediated by GABA-A R activation. For GABA synthesis, murine NK cells expressed both GAD65 and GAD67, similar to murine microglia [43]. In contrast, human NK cells exclusively expressed GAD67 indicating a key role for this enzyme in GABA production. Related to transportation of GABA, only transcripts of GAT2 were detected in both human and murine NK cells. This contrasts with the expression of GAT2 and GAT4 by murine microglia and DCs $[35,43]$ and GAT1 was dysregulated in T cells $[9,51]$. The expression of GAT2, jointly with GAD67 expression, indicates that GABA is synthesized cytosolically and secreted in vesicle-independent fashion for tonic modulations of GABA-A Rs in NK cells, as described in neurons $[57,58,122]$. Moreover, the reciprocal upregulation of GAD67 and downregulation of GABA-catabolizing GABA-T upon infection was consistent is human donors, indicating a tightly regulated GABA production in NK cells.

\section{Impact of GABAergic activation on NK cell effector functions}

Importantly, in an infection challenge model, GABAergic activation in NK cells impacted their effector functions and interactions with DCs [54]. Upon challenge with $T$. gon$d i i$, NK cells responded with GABA secretion. Importantly, 
GABA secreted by parasitized NK cells (and DCs) hampered cytotoxicity and degranulation of NK cells in vitro. Additionally, GABA secreted by NK cells also modulated the migratory responses of DCs. GABA modulates cytokine release by peripheral blood mononuclear cells and $\mathrm{T}$ cells [50], and T-cell cytotoxicity [123], but its effects on NKcell function have remained unclear [124]. Hypothetically, GABA may exert dual effects upon infection and inflammation: down-modulate pro-inflammatory responses and enhance DC migration [54]. In the context of infection in tissues, this dual effect may dampen inflammation but also modulate NK-DC interactions.

The precise mechanisms of downmodulation of NK cell responses by GABA remain uncharacterized. However, it was recently shown that GABA signaling is linked to MAP kinase activation in DCs [68] and MAP kinases regulate cytokine responses [125], which are inhibited by GABA in $\mathrm{T}$ cells [50]. Thus, it is likely that the immunomodulatory effects of GABA on NK cells are mediated by MAP kinase signaling. Additionally, future investigations need to address if GABAergic signaling acts on NK cells via effector VDCCs, as shown in DCs [34].

\section{B cells and granulocytes}

To date, little is known about the expression of GABAergic components by B cells and granulocytes (neutrophils, eosinophils, basophils, and mast cells), which carry out crucial adaptive and innate immune functions, respectively.

Experimental evidence of functional GABAergic signaling by $\mathrm{B}$ cells is missing. However, in human B-cell lysates, western blot signal corresponding to GABA-A R $\alpha 1$ subunit was detected and GABA-A R $\alpha 3, \beta 2$ subunit mRNA was amplified from human irradiated B cells [48].

In neutrophils, GABA-B Rs have been attributed a role in chemotaxis and been associated with neutrophil recruitment to inflammatory sites [56, 126, 127] (Table 1). Evidence of GABAergic expression and mechanistic studies are missing for eosinophils and basophils. However, Gabra4 knock-out mice exhibited increased eosinophilic lung infiltration [128] and GABA antagonism decreased eosinophils in bronchoalveolar lavage in murine asthma models [129], indicating direct or indirect implication of GABA.

Thus, compelling evidence or functional data for GABAergic signaling in $\mathrm{B}$ cells and granulocytes are at present scarce or absent. However, the data indicate expression of GABAergic components or responsiveness to GABA, further underscoring the general expression of GABAergic system in cells of the immune system.

\section{Perspectives}

The amino acid GABA is not incorporated into proteins. Instead, GABA serves as a signaling molecule and metabolic molecule in prokaryotes and eukaryotes. In the evolved vertebrate CNS, GABA has developed into an essential neurotransmitter. It is now clear that novel biological functions can be attributed to this versatile molecule. Given its expression and diverse functions in leukocytes, it is likely that GABAergic signaling is conserved throughout the immune system. The diversity of expressed GABAergic components in immune cells is likely also an indicator of yet undiscovered functions in the immune system. Recently emerged immunomodulatory functions of GABA include cytokine secretion, proliferation, cytotoxicity, migration and chemotaxis (Fig. 1, Table 1). The impact of GABA on phagocyte migration is in fact reminiscent of the motogenic role of GABA for embryonic interneuron migration in the developing fetus [18]. Furthermore, the putative impact of GABA on crucial interactions between immune cells needs to be explored, because it could open up for novel immunomodulatory approaches. These include, for example, the interactions between antigen presenting cells and $\mathrm{T}$ cells, between $\mathrm{T}$ and $\mathrm{B}$ cells in adaptive immune responses, or cytotoxic NK- and T-cell responses [130].

However, GABA is not only an intercellular signaling molecule between leukocytes but can also be considered an interspecies signaling molecule in host-microbe interactions. Recent reports show that bacteria, protozoan parasites and viruses modulate GABAergic signaling in immune cells for survival and colonization, including hijacking of leukocyte migration [34, 35, 37, 74]. These findings also raise the question whether microbial GABA or its metabolites are detected by sensing pathways of the immune system that detect specific dietary and microbial metabolites [131].

From a clinical perspective, GABA signaling has newly been associated with cancer metastasis [63, 64], for instance pancreatic cancer, breast cancer and gliomas $[8$, 10, 132]. Furthermore, the implication of GABA signaling in various autoimmune diseases, such as multiple sclerosis [9], type I diabetes [11, 50] and rheumatoid arthritis [105], indicates a general role in inflammatory responses. Future research needs to address if the motogenic effects in leukocytes are also implicated in inflammatory responses and in cancer cell metastasis. Hypothetically, receptor sub-types or other GABAergic components may be targeted pharmacologically to modulate migration and inflammatory responses of GABAergic cells [65].

The multiple points of interaction and communication exist between the CNS and the immune system have become increasingly evident [133]. Understanding neuro-immune interactions have not only advanced our understanding of 
immunity but also identified new therapeutic possibilities in inflammatory and autoimmune disease. From this perspective, the biology associated with GABA and other neuroactive molecules in immune cells represents an emerging field.

Acknowledgements We thank all contributing scientists and apologize to all those whose original work was not cited due to space limitations.

Authors contributions All authors contributed to the writing of this manuscript.

Funding Open access funding provided by Stockholm University. This work was funded by the Swedish Research Council (Vetenskapsrådet, 2018-02411) and the Olle Engkvist Byggmästare Foundation (193-609)

Data availability The datasets used and analyzed in this study are available from the corresponding author on reasonable request.

\section{Declarations}

Conflict of interest The authors declare that there is no duality of interest associated with this manuscript.

Open Access This article is licensed under a Creative Commons Attribution 4.0 International License, which permits use, sharing, adaptation, distribution and reproduction in any medium or format, as long as you give appropriate credit to the original author(s) and the source, provide a link to the Creative Commons licence, and indicate if changes were made. The images or other third party material in this article are included in the article's Creative Commons licence, unless indicated otherwise in a credit line to the material. If material is not included in the article's Creative Commons licence and your intended use is not permitted by statutory regulation or exceeds the permitted use, you will need to obtain permission directly from the copyright holder. To view a copy of this licence, visit http://creativecommons.org/licenses/by/4.0/.

\section{References}

1. Steward FC, Thompson JF, Dent CE (1949) $\gamma$-aminobutyric acid: a constituent of the potato tuber? Science 110:439-440

2. Roberts E, Frankel S (1950) Gamma-aminobutyric acid in brain: its formation from glutamic acid. J Biol Chem 187(1):55-63

3. Roth RJ, Cooper JR, Bloom FE (2003) The biochemical basis of neuropharmacology. Oxford University Press, Oxford [Oxfordshire], p 106 (ISBN 978-0-19-514008-8)

4. Ueno H (2000) Enzymatic and structural aspects on glutamate decarboxylase. J Mol Catal B Enzym 10(1-3):67-79. https://doi. org/10.1016/S1381-1177(00)00114-4

5. Erdo SL, Wolff JR (1990) Gamma-aminobutyric acid outside the mammalian brain. J Neurochem 54(2):363-372. https://doi.org/ 10.1111/j.1471-4159.1990.tb01882.x

6. Gladkevich A, Korf J, Hakobyan VP, Melkonyan KV (2006) The peripheral GABAergic system as a target in endocrine disorders. Auton Neurosci 124(1-2):1-8. https://doi.org/10.1016/j.autneu. 2005.11.002

7. Ben-Othman N, Vieira A, Courtney M, Record F, Gjernes E, Avolio F, Hadzic B, Druelle N, Napolitano T, Navarro-Sanz S, Silvano S, Al-Hasani K, Pfeifer A, Lacas-Gervais S, Leuckx G, Marroqui L, Thevenet J, Madsen OD, Eizirik DL, Heimberg H,
Kerr-Conte J, Pattou F, Mansouri A, Collombat P (2017) Longterm GABA administration induces alpha cell-mediated betalike cell neogenesis. Cell 168(1-2):73-85.e11. https://doi.org/ 10.1016/j.cell.2016.11.002

8. Neman J, Termini J, Wilczynski S, Vaidehi N, Choy C, Kowolik CM, Li H, Hambrecht AC, Roberts E, Jandial R (2014) Human breast cancer metastases to the brain display GABAergic properties in the neural niche. Proc Natl Acad Sci USA 111(3):984989. https://doi.org/10.1073/pnas.1322098111

9. Bhat R, Axtell R, Mitra A, Miranda M, Lock C, Tsien RW, Steinman L (2010) Inhibitory role for GABA in autoimmune inflammation. Proc Natl Acad Sci USA 107(6):2580-2585. https://doi. org/10.1073/pnas.0915139107 (0915139107[pii])

10. Takehara A, Hosokawa M, Eguchi H, Ohigashi H, Ishikawa O, Nakamura Y, Nakagawa H (2007) Gamma-aminobutyric acid (GABA) stimulates pancreatic cancer growth through overexpressing GABAA receptor pi subunit. Cancer Res 67(20):97049712. https://doi.org/10.1158/0008-5472.CAN-07-2099

11. Li J, Casteels T, Frogne T, Ingvorsen C, Honore C, Courtney M, Huber KV, Schmitner N, Kimmel RA, Romanov RA, Sturtzel C, Lardeau CH, Klughammer J, Farlik M, Sdelci S, Vieira A, Avolio F, Briand F, Baburin I, Majek P, Pauler FM, Penz T, Stukalov A, Gridling M, Parapatics K, Barbieux C, Berishvili E, Spittler A, Colinge J, Bennett KL, Hering S, Sulpice T, Bock C, Distel M, Harkany T, Meyer D, Superti-Furga G, Collombat P, Hecksher-Sorensen J, Kubicek S (2017) Artemisinins target GABAA receptor signaling and impair alpha cell identity. Cell 168(1-2):86-100.e115. https://doi.org/10.1016/j.cell.2016.11. 010

12. Soghomonian JJ, Martin DL (1998) Two isoforms of glutamate decarboxylase: why? Trends Pharmacol Sci 19(12):500-505

13. Hoglund PJ, Adzic D, Scicluna SJ, Lindblom J, Fredriksson R (2005) The repertoire of solute carriers of family 6: identification of new human and rodent genes. Biochem Biophys Res Commun 336(1):175-189. https://doi.org/10.1016/j.bbrc.2005.08.048

14. Olsen RW, Sieghart W (2008) International union of pharmacology. LXX. Subtypes of gamma-aminobutyric acid (A) receptors: classification on the basis of subunit composition, pharmacology, and function. Update. Pharmacol Rev 60(3):243-260. https://doi. org/10.1124/pr.108.00505

15. Bettler B, Kaupmann K, Mosbacher J, Gassmann M (2004) Molecular structure and physiological functions of GABA (B) receptors. Physiol Rev 84(3):835-867. https://doi.org/10.1152/ physrev.00036.2003

16. Uusi-Oukari M, Korpi ER (2010) Regulation of GABA (A) receptor subunit expression by pharmacological agents. Pharmacol Rev 62(1):97-135. https://doi.org/10.1124/pr.109.002063

17. Kaila K, Price TJ, Payne JA, Puskarjov M, Voipio J (2014) Cation-chloride cotransporters in neuronal development, plasticity and disease. Nat Rev Neurosci 15(10):637-654. https://doi.org/ 10.1038/nrn3819

18. Bortone D, Polleux F (2009) KCC2 expression promotes the termination of cortical interneuron migration in a voltage-sensitive calcium-dependent manner. Neuron 62(1):53-71. https://doi.org/ 10.1016/j.neuron.2009.01.034

19. Farrant M, Nusser Z (2005) Variations on an inhibitory theme: phasic and tonic activation of GABA (A) receptors. Nat Rev Neurosci 6(3):215-229. https://doi.org/10.1038/nrn1625

20. Brickley SG, Mody I (2012) Extrasynaptic GABA (A) receptors: their function in the CNS and implications for disease. Neuron 73(1):23-34. https://doi.org/10.1016/j.neuron.2011.12.012

21. Jin Z, Jin Y, Kumar-Mendu S, Degerman E, Groop L, Birnir B (2011) Insulin reduces neuronal excitability by turning on GABA (A) channels that generate tonic current. PLoS ONE 6(1):e16188. https://doi.org/10.1371/journal.pone.0016188 
22. de Groote L, Linthorst AC (2007) Exposure to novelty and forced swimming evoke stressor-dependent changes in extracellular GABA in the rat hippocampus. Neuroscience 148(3):794805. https://doi.org/10.1016/j.neuroscience.2007.06.030 (S0306-4522(07)00856-1[pii])

23. Petty F, Sherman AD (1984) Plasma GABA levels in psychiatric illness. J Affect Disord 6(2):131-138 (0165-0327(84)90018-1[pii])

24. Semyanov A, Walker MC, Kullmann DM (2003) GABA uptake regulates cortical excitability via cell type-specific tonic inhibition. Nat Neurosci 6(5):484-490 (10.1038/nn1043.nn1043[pii])

25. Laurenti E, Gottgens B (2018) From haematopoietic stem cells to complex differentiation landscapes. Nature 553(7689):418-426. https://doi.org/10.1038/nature25022

26. Iwasaki A, Medzhitov R (2015) Control of adaptive immunity by the innate immune system. Nat Immunol 16(4):343-353. https:// doi.org/10.1038/ni.3123

27. Olofsson PS, Rosas-Ballina M, Levine YA, Tracey KJ (2012) Rethinking inflammation: neural circuits in the regulation of immunity. Immunol Rev 248(1):188-204. https://doi.org/10. 1111/j.1600-065X.2012.01138.x

28. Levite M (2012) Nerve-driven immunity. Neurotransmitters and neuropeptides in the immune system. Springer. https://doi.org/ 10.1016/j.bbi.2012.12.009 (ISBN 978-3-7091-0887-1)

29. Guilliams M, Ginhoux F, Jakubzick C, Naik SH, Onai N, Schraml BU, Segura E, Tussiwand R, Yona S (2014) Dendritic cells, monocytes and macrophages: a unified nomenclature based on ontogeny. Nat Rev Immunol 14(8):571-578. https://doi.org/10. 1038/nri3712

30. Alvarez D, Vollmann EH, von Andrian UH (2008) Mechanisms and consequences of dendritic cell migration. Immunity 29(3):325-342. https://doi.org/10.1016/j.immuni.2008.08.006

31. Forster R, Davalos-Misslitz AC, Rot A (2008) CCR7 and its ligands: balancing immunity and tolerance. Nat Rev Immunol 8(5):362-371. https://doi.org/10.1038/nri2297 (nri2297[pii])

32. Sacks D, Sher A (2002) Evasion of innate immunity by parasitic protozoa. Nat Immunol 3(11):1041-1047

33. Steinman RM, Banchereau J (2007) Taking dendritic cells into medicine. Nature 449(7161):419-426 (nature06175[pii])

34. Bhandage AK, Olivera GC, Kanatani S, Thompson E, Lore K, Varas-Godoy M, Barragan A (2020) A motogenic GABAergic system of mononuclear phagocytes facilitates dissemination of coccidian parasites. Elife. https://doi.org/10.7554/eLife.60528

35. Fuks JM, Arrighi RB, Weidner JM, Kumar Mendu S, Jin Z, Wallin RP, Rethi B, Birnir B, Barragan A (2012) GABAergic signaling is linked to a hypermigratory phenotype in dendritic cells infected by Toxoplasma gondii. PLoS Pathog 8(12):e1003051. https://doi.org/10.1371/journal.ppat.1003051

36. Kanatani S, Fuks JM, Olafsson EB, Westermark L, Chambers B, Varas-Godoy M, Uhlen P, Barragan A (2017) Voltage-dependent calcium channel signaling mediates GABAA receptor-induced migratory activation of dendritic cells infected by Toxoplasma gondii. PLoS Pathog 13(12):e1006739. https://doi.org/10.1371/ journal.ppat.1006739

37. Kim JK, Kim YS, Lee HM, Jin HS, Neupane C, Kim S, Lee SH, Min JJ, Sasai M, Jeong JH, Choe SK, Kim JM, Yamamoto M, Choy HE, Park JB, Jo EK (2018) GABAergic signaling linked to autophagy enhances host protection against intracellular bacterial infections. Nat Commun 9(1):4184. https://doi.org/10.1038/ s41467-018-06487-5

38. Xia Y, He F, Wu X, Tan B, Chen S, Liao Y, Qi M, Chen S, Peng Y, Yin Y, Ren W (2021) GABA transporter sustains IL-1beta production in macrophages. Sci Adv. https://doi.org/10.1126/ sciadv.abe9274
39. Reyes-Garcia MG, Hernandez-Hernandez F, Hernandez-Tellez B, Garcia-Tamayo F (2007) GABA (A) receptor subunits RNA expression in mice peritoneal macrophages modulate their IL-6/ IL-12 production. J Neuroimmunol 188(1-2):64-68. https://doi. org/10.1016/j.jneuroim.2007.05.013

40. Wheeler DW, Thompson AJ, Corletto F, Reckless J, Loke JC, Lapaque N, Grant AJ, Mastroeni P, Grainger DJ, Padgett CL, O'Brien JA, Miller NG, Trowsdale J, Lummis SC, Menon DK, Beech JS (2011) Anaesthetic impairment of immune function is mediated via GABA (A) receptors. PLoS ONE 6(2):e17152. https://doi.org/10.1371/journal.pone.0017152

41. Robert V, Triffaux E, Paulet PE, Guery JC, Pelletier L, Savignac M (2014) Protein kinase C-dependent activation of CaV1.2 channels selectively controls human TH2-lymphocyte functions. J Allergy Clin Immunol 133(4):1175-1183. https://doi.org/10. 1016/j.jaci.2013.10.038

42. Lee M, Schwab C, McGeer PL (2011) Astrocytes are GABAergic cells that modulate microglial activity. Glia 59(1):152-165. https://doi.org/10.1002/glia.21087

43. Bhandage AK, Kanatani S, Barragan A (2019) Toxoplasmainduced hypermigration of primary cortical microglia implicates GABAergic signaling. Front Cell Infect Microbiol 9:73. https:// doi.org/10.3389/fcimb.2019.00073

44. Kuhn SA, van Landeghem FK, Zacharias R, Farber K, Rappert A, Pavlovic S, Hoffmann A, Nolte C, Kettenmann H (2004) Microglia express GABA (B) receptors to modulate interleukin release. Mol Cell Neurosci 25(2):312-322. https://doi.org/10. 1016/j.mcn.2003.10.023

45. Mendu SK, Bhandage A, Jin Z, Birnir B (2012) Different subtypes of GABA-A receptors are expressed in human, mouse and rat T lymphocytes. PLoS ONE 7(8):e42959. https://doi.org/10. 1371/journal.pone.0042959

46. Dionisio L, Jose De Rosa M, Bouzat C, Esandi Mdel C (2011) An intrinsic GABAergic system in human lymphocytes. Neuropharmacology 60(2-3):513-519. https://doi.org/10.1016/j.neuro pharm.2010.11.007

47. Kotturi MF, Carlow DA, Lee JC, Ziltener HJ, Jefferies WA (2003) Identification and functional characterization of voltagedependent calcium channels in T lymphocytes. J Biol Chem 278(47):46949-46960. https://doi.org/10.1074/jbc.M309268200

48. Alam S, Laughton DL, Walding A, Wolstenholme AJ (2006) Human peripheral blood mononuclear cells express GABAA receptor subunits. Mol Immunol 43(9):1432-1442. https://doi. org/10.1016/j.molimm.2005.07.025

49. Stokes L, Gordon J, Grafton G (2004) Non-voltage-gated L-type $\mathrm{Ca} 2+$ channels in human $\mathrm{T}$ cells: pharmacology and molecular characterization of the major alpha pore-forming and auxiliary beta-subunits. J Biol Chem 279(19):19566-19573. https://doi. org/10.1074/jbc.M401481200

50. Bhandage AK, Jin Z, Korol SV, Shen Q, Pei Y, Deng Q, Espes D, Carlsson PO, Kamali-Moghaddam M, Birnir B (2018) GABA regulates release of inflammatory cytokines from peripheral blood mononuclear cells and CD4(+) T cells and is immunosuppressive in type 1 diabetes. EBioMedicine 30:283-294. https:// doi.org/10.1016/j.ebiom.2018.03.019

51. Wang Y, Feng D, Liu G, Luo Q, Xu Y, Lin S, Fei J, Xu L (2008) Gamma-aminobutyric acid transporter 1 negatively regulates $\mathrm{T}$ cell-mediated immune responses and ameliorates autoimmune inflammation in the CNS. J Immunol 181(12):8226-8236. https://doi.org/10.4049/jimmunol.181.12.8226

52. Kochl R, Thelen F, Vanes L, Brazao TF, Fountain K, Xie J, Huang CL, Lyck R, Stein JV, Tybulewicz VL (2016) WNK1 kinase balances $\mathrm{T}$ cell adhesion versus migration in vivo. Nat Immunol 17(9):1075-1083. https://doi.org/10.1038/ni.3495 
53. Wang H, Zhang X, Xue L, Xing J, Jouvin MH, Putney JW, Anderson MP, Trebak M, Kinet JP (2016) Low-voltage-activated CaV3.1 calcium channels shape $\mathrm{T}$ helper cell cytokine profiles. Immunity 44(4):782-794. https://doi.org/10.1016/j.immuni. 2016.01.015

54. Bhandage AK, Friedrich LM, Kanatani S, Jakobsson-Björkén S, Escrig-Larena JI, Wagner AK, Chambers BJ, Barragan A (2021) GABAergic signaling in human and murine NK cells upon challenge with Toxoplasma gondii. J Leukoc Biol J Leukoc Biol. https://doi.org/10.1002/JLB.3HI0720-431R

55. Grafton G, Stokes L, Toellner KM, Gordon J (2003) A non-voltage-gated calcium channel with L-type characteristics activated by B cell receptor ligation. Biochem Pharmacol 66(10):20012009. https://doi.org/10.1016/j.bcp.2003.07.005

56. Rane MJ, Gozal D, Butt W, Gozal E, Pierce WM Jr, Guo SZ, Wu R, Goldbart AD, Thongboonkerd V, McLeish KR, Klein JB (2005) Gamma-amino butyric acid type B receptors stimulate neutrophil chemotaxis during ischemia-reperfusion. J Immunol 174(11):7242-7249. https://doi.org/10.4049/jimmunol.174.11. 7242

57. Kaufman DL, Houser CR, Tobin AJ (1991) Two forms of the gamma-aminobutyric acid synthetic enzyme glutamate decarboxylase have distinct intraneuronal distributions and cofactor interactions. J Neurochem 56(2):720-723. https://doi.org/10. 1111/j.1471-4159.1991.tb08211.x

58. Feldblum S, Erlander MG, Tobin AJ (1993) Different distributions of GAD65 and GAD67 mRNAs suggest that the two glutamate decarboxylases play distinctive functional roles. J Neurosci Res 34(6):689-706. https://doi.org/10.1002/jnr.490340612

59. Davis AM, Penschuck S, Fritschy JM, McCarthy MM (2000) Developmental switch in the expression of GABA (A) receptor subunits alpha (1) and alpha (2) in the hypothalamus and limbic system of the rat. Brain Res Dev Brain Res 119(1):127-138. https://doi.org/10.1016/s0165-3806(99)00150-9

60. Goetz T, Arslan A, Wisden W, Wulff P (2007) GABA (A) receptors: structure and function in the basal ganglia. Prog Brain Res 160:21-41. https://doi.org/10.1016/S0079-6123(06)60003-4

61. Lambert H, Hitziger N, Dellacasa I, Svensson M, Barragan A (2006) Induction of dendritic cell migration upon Toxoplasma gondii infection potentiates parasite dissemination. Cell Microbiol 8(10):1611-1623. https://doi.org/10.1111/j.1462-5822.2006. 00735.x

62. Weidner JM, Barragan A (2014) Tightly regulated migratory subversion of immune cells promotes the dissemination of Toxoplasma gondii. Int J Parasitol 44(2):85-90. https://doi.org/10. 1016/j.ijpara.2013.09.006

63. Sizemore GM, Sizemore ST, Seachrist DD, Keri RA (2014) GABA (A) receptor pi (GABRP) stimulates basal-like breast cancer cell migration through activation of extracellular-regulated kinase 1/2 (ERK1/2). J Biol Chem 289(35):24102-24113. https:// doi.org/10.1074/jbc.M114.593582

64. Wu W, Yang Q, Fung KM, Humphreys MR, Brame LS, Cao A, Fang YT, Shih PT, Kropp BP, Lin HK (2014) Linking gammaaminobutyric acid A receptor to epidermal growth factor receptor pathways activation in human prostate cancer. Mol Cell Endocrinol 383(1-2):69-79. https://doi.org/10.1016/j.mce.2013.11. 017

65. Miao Y, Zhang Y, Wan H, Chen L, Wang F (2010) GABA-receptor agonist, propofol inhibits invasion of colon carcinoma cells. Biomed Pharmacother 64(9):583-588. https://doi.org/10.1016/j. biopha.2010.03.006

66. Weidner JM, Kanatani S, Hernandez-Castaneda MA, Fuks JM, Rethi B, Wallin RP, Barragan A (2013) Rapid cytoskeleton remodelling in dendritic cells following invasion by Toxoplasma gondii coincides with the onset of a hypermigratory phenotype.
Cell Microbiol 15(10):1735-1752. https://doi.org/10.1111/cmi. 12145

67. Olafsson EB, Ross EC, Varas-Godoy M, Barragan A (2019) TIMP-1 promotes hypermigration of Toxoplasma-infected primary dendritic cells via CD63-ITGB1-FAK signaling. J Cell Sci. https://doi.org/10.1242/jcs.225193

68. Olafsson EB, Ten Hoeve AL, Li-Wang X, Westermark L, VarasGodoy M, Barragan A (2020) Convergent met and voltage-gated $\mathrm{Ca}(2+)$ channel signaling drives hypermigration of Toxoplasmainfected dendritic cells. J Cell Sci. https://doi.org/10.1242/jcs. 241752

69. Behar TN, Schaffner AE, Colton CA, Somogyi R, Olah Z, Lehel C, Barker JL (1994) GABA-induced chemokinesis and NGFinduced chemotaxis of embryonic spinal cord neurons. J Neurosci 14(1):29-38

70. Azuma H, Inamoto T, Sakamoto T, Kiyama S, Ubai T, Shinohara Y, Maemura K, Tsuji M, Segawa N, Masuda H, Takahara K, Katsuoka Y, Watanabe M (2003) Gamma-aminobutyric acid as a promoting factor of cancer metastasis; induction of matrix metalloproteinase production is potentially its underlying mechanism. Cancer Res 63(23):8090-8096

71. Calogero AE, Hall J, Fishel S, Green S, Hunter A, D'Agata R (1996) Effects of gamma-aminobutyric acid on human sperm motility and hyperactivation. Mol Hum Reprod 2(10):733-738

72. Sanders RD, Godlee A, Fujimori T, Goulding J, Xin G, SalekArdakani S, Snelgrove RJ, Ma D, Maze M, Hussell T (2013) Benzodiazepine augmented gamma-amino-butyric acid signaling increases mortality from pneumonia in mice. Crit Care Med 41(7):1627-1636. https://doi.org/10.1097/CCM.0b013e3182 $7 \mathrm{c} 0 \mathrm{c} 8 \mathrm{~d}$

73. Januzi L, Poirier JW, Maksoud MJE, Xiang YY, Veldhuizen RAW, Gill SE, Cregan SP, Zhang H, Dekaban GA, Lu WY (2018) Autocrine GABA signaling distinctively regulates phenotypic activation of mouse pulmonary macrophages. Cell Immunol 332:7-23. https://doi.org/10.1016/j.cellimm.2018.07.001

74. Zhu Y, Zhang R, Zhang B, Zhao T, Wang P, Liang G, Cheng $G$ (2017) Blood meal acquisition enhances arbovirus replication in mosquitoes through activation of the GABAergic system. Nat Commun 8(1):1262. https://doi.org/10.1038/ s41467-017-01244-6

75. Falk-Petersen CB, Tsonkov TM, Nielsen MS, Harpsoe K, Bundgaard C, Frolund B, Kristiansen U, Gloriam DE, Wellendorph P (2020) Discovery of a new class of orthosteric antagonists with nanomolar potency at extrasynaptic GABAA receptors. Sci Rep 10(1):10078. https://doi.org/10.1038/s41598-020-66821-0

76. Tian J, Middleton B, Lee VS, Park HW, Zhang Z, Kim B, Lowe C, Nguyen N, Liu H, Beyer RS, Chao HW, Chen R, Mai D, O'Laco KA, Song M, Kaufman DL (2021) GABAB-receptor agonist-based immunotherapy for type 1 diabetes in NOD mice. Biomedicines. https://doi.org/10.3390/biomedicines9010043

77. Neumann S, Boothman-Burrell L, Gowing EK, Jacobsen TA, Ahring PK, Young SL, Sandager-Nielsen K, Clarkson AN (2019) The delta-subunit selective GABA A receptor modulator, DS2, improves stroke recovery via an anti-inflammatory mechanism. Front Neurosci 13:1133. https://doi.org/10.3389/fnins.2019. 01133

78. Kaila K (1994) Ionic basis of GABAA receptor channel function in the nervous system. Prog Neurobiol 42(4):489-537. https:// doi.org/10.1016/0301-0082(94)90049-3

79. Martin C, Pedersen SF, Schwab A, Stock C (2011) Intracellular $\mathrm{pH}$ gradients in migrating cells. Am J Physiol Cell Physiol 300(3):C490-495. https://doi.org/10.1152/ajpcell.00280.2010

80. Rajamaki K, Nordstrom T, Nurmi K, Akerman KE, Kovanen PT, Oorni K, Eklund KK (2013) Extracellular acidosis is a novel danger signal alerting innate immunity via the NLRP3 
inflammasome. J Biol Chem 288(19):13410-13419. https://doi. org/10.1074/jbc.M112.426254

81. Ginhoux F, Greter M, Leboeuf M, Nandi S, See P, Gokhan S, Mehler MF, Conway SJ, Ng LG, Stanley ER, Samokhvalov IM, Merad M (2010) Fate mapping analysis reveals that adult microglia derive from primitive macrophages. Science 330(6005):841845. https://doi.org/10.1126/science. 1194637

82. Nimmerjahn A, Kirchhoff F, Helmchen F (2005) Resting microglial cells are highly dynamic surveillants of brain parenchyma in vivo. Science 308(5726):1314-1318

83. Thurgur H, Pinteaux E (2019) Microglia in the neurovascular unit: blood-brain barrier-microglia interactions after central nervous system disorders. Neuroscience 405:55-67. https://doi.org/ 10.1016/j.neuroscience.2018.06.046

84. Cao T, Thomas TC, Ziebell JM, Pauly JR, Lifshitz J (2012) Morphological and genetic activation of microglia after diffuse traumatic brain injury in the rat. Neuroscience 225:65-75. https:// doi.org/10.1016/j.neuroscience.2012.08.058

85. Han Q, Liu S, Li Z, Hu F, Zhang Q, Zhou M, Chen J, Lei T, Zhang H (2014) DCPIB, a potent volume-regulated anion channel antagonist, attenuates microglia-mediated inflammatory response and neuronal injury following focal cerebral ischemia. Brain Res 1542:176-185. https://doi.org/10.1016/j.brainres. 2013.10.026

86. Cheung G, Kann O, Kohsaka S, Faerber K, Kettenmann H (2009) GABAergic activities enhance macrophage inflammatory protein-1alpha release from microglia (brain macrophages) in postnatal mouse brain. J Physiol 587:753-768. https://doi.org/ 10.1113/jphysiol.2008.163923 (Pt 4)

87. John B, Ricart B, Tait Wojno ED, Harris TH, Randall LM, Christian DA, Gregg B, De Almeida DM, Weninger W, Hammer DA, Hunter CA (2011) Analysis of behavior and trafficking of dendritic cells within the brain during Toxoplasmic encephalitis. PLoS Pathog 7(9):e1002246. https://doi.org/10.1371/journal. ppat. 1002246

88. Brooks JM, Carrillo GL, Su J, Lindsay DS, Fox MA, Blader IJ (2015) Toxoplasma gondii infections alter GABAergic synapses and signaling in the central nervous system. MBio 6(6):e01428-e11415. https://doi.org/10.1128/mBio.01428-15

89. Weidner JM, Kanatani S, Uchtenhagen H, Varas-Godoy M, Schulte T, Engelberg K, Gubbels MJ, Sun HS, Harrison RE, Achour A, Barragan A (2016) Migratory activation of parasitized dendritic cells by the protozoan Toxoplasma gondii 14-3-3 protein. Cell Microbiol. https://doi.org/10.1111/cmi.12595

90. Fontainhas AM, Wang M, Liang KJ, Chen S, Mettu P, Damani M, Fariss RN, Li W, Wong WT (2011) Microglial morphology and dynamic behavior is regulated by ionotropic glutamatergic and GABAergic neurotransmission. PLoS ONE 6(1):e15973. https://doi.org/10.1371/journal.pone.0015973

91. Kumar BV, Connors TJ, Farber DL (2018) Human T cell development, localization, and function throughout life. Immunity 48(2):202-213. https://doi.org/10.1016/j.immuni.2018.01.007

92. Barragan A, Weidner JM, Jin Z, Korpi ER, Birnir B (2015) GABAergic signalling in the immune system. Acta Physiol 213(4):819-827. https://doi.org/10.1111/apha.12467

93. Birnir B, Korpi ER (2007) The impact of sub-cellular location and intracellular neuronal proteins on properties of GABA (A) receptors. Curr Pharm Des 13(31):3169-3177

94. Jin Z, Mendu SK, Birnir B (2013) GABA is an effective immunomodulatory molecule. Amino Acids 45(1):87-94

95. Bhandage AK, Hellgren C, Jin Z, Olafsson EB, Sundstrom-Poromaa I, Birnir B (2015) Expression of GABA receptors subunits in peripheral blood mononuclear cells is gender dependent, altered in pregnancy and modified by mental health. Acta Physiol 213(3):575-585. https://doi.org/10.1111/apha.12440
96. Lozano-Ojalvo D, López-Fandiño R, López-Expósito I (2015) PBMC-derived T cells. In: Verhoeckx K, Cotter P, LópezExpósito I (eds) The impact of food bioactives on health: in vitro and ex vivo models. Springer International Publishing, Cham, pp 169-180. https://doi.org/10.1007/978-3-319-16104-4_16

97. Tian J, Chau C, Hales TG, Kaufman DL (1999) GABA (A) receptors mediate inhibition of $\mathrm{T}$ cell responses. J Neuroimmunol 96(1):21-28 (S0165-5728(98)00264-1[pii])

98. Prud'homme GJ, Glinka Y, Hasilo C, Paraskevas S, Li X, Wang Q (2013) GABA protects human islet cells against the deleterious effects of immunosuppressive drugs and exerts immunoinhibitory effects alone. Transplantation 96(7):616-623. https://doi. org/10.1097/TP.0b013e31829c24be

99. Bjurstom H, Wang J, Ericsson I, Bengtsson M, Liu Y, KumarMendu S, Issazadeh-Navikas S, Birnir B (2008) GABA, a natural immunomodulator of T lymphocytes. J Neuroimmunol 205(12):44-50. https://doi.org/10.1016/j.jneuroim.2008.08.017

100. Wei M, Li L, Meng R, Fan Y, Liu Y, Tao L, Liu X, Wu C (2010) Suppressive effect of diazepam on IFN-gamma production by human T cells. Int Immunopharmacol 10(3):267-271. https:// doi.org/10.1016/j.intimp.2009.11.009

101. Soltani N, Qiu H, Aleksic M, Glinka Y, Zhao F, Liu R, Li Y, Zhang N, Chakrabarti R, Ng T, Jin T, Zhang H, Lu WY, Feng ZP, Prud'homme GJ, Wang Q (2011) GABA exerts protective and regenerative effects on islet beta cells and reverses diabetes. Proc Natl Acad Sci U S A 108(28):11692-11697. https://doi.org/ 10.1073/pnas.1102715108

102. Tian J, Lu Y, Zhang H, Chau CH, Dang HN, Kaufman DL (2004) Gamma-aminobutyric acid inhibits $\mathrm{T}$ cell autoimmunity and the development of inflammatory responses in a mouse type 1 diabetes model. J Immunol 173(8):5298-5304. https://doi.org/10. 4049/jimmunol.173.8.5298

103. Tian J, Dang H, Nguyen AV, Chen Z, Kaufman DL (2014) Combined therapy with GABA and proinsulin/alum acts synergistically to restore long-term normoglycemia by modulating T-cell autoimmunity and promoting beta-cell replication in newly diabetic NOD mice. Diabetes 63(9):3128-3134. https://doi.org/10. 2337/db13-1385

104. Demakova EV, Korobov VP, Lemkina LM (2003) Determination of gamma-aminobutyric acid concentration and activity of glutamate decarboxylase in blood serum of patients with multiple sclerosis. Klin Lab Diagn 4:15-17

105. Tian J, Yong J, Dang H, Kaufman DL (2011) Oral GABA treatment downregulates inflammatory responses in a mouse model of rheumatoid arthritis. Autoimmunity 44(6):465-470. https:// doi.org/10.3109/08916934.2011.571223

106. Nigam R, El-Nour H, Amatya B, Nordlind K (2010) GABA and GABA (A) receptor expression on immune cells in psoriasis: a pathophysiological role. Arch Dermatol Res 302(7):507-515. https://doi.org/10.1007/s00403-010-1052-5

107. Bhandage AK, Jin Z, Korol SV, Tafreshiha AS, Gohel P, Hellgren C, Espes D, Carlsson PO, Sundstrom-Poromaa I, Birnir B (2018) Expression of calcium release-activated and voltagegated calcium channels genes in peripheral blood mononuclear cells is altered in pregnancy and in type 1 diabetes. PLoS ONE 13(12):e0208981. https://doi.org/10.1371/journal.pone.0208981

108. Omilusik K, Priatel JJ, Chen X, Wang YT, Xu H, Choi KB, Gopaul R, McIntyre-Smith A, Teh HS, Tan R, Bech-Hansen NT, Waterfield D, Fedida D, Hunt SV, Jefferies WA (2011) The $\mathrm{Ca}(\mathrm{v}) 1.4$ calcium channel is a critical regulator of $\mathrm{T}$ cell receptor signaling and naive T cell homeostasis. Immunity 35(3):349360. https://doi.org/10.1016/j.immuni.2011.07.011

109. Jha MK, Badou A, Meissner M, McRory JE, Freichel M, Flockerzi V, Flavell RA (2009) Defective survival of naive CD8+ T lymphocytes in the absence of the beta3 regulatory subunit of 
voltage-gated calcium channels. Nat Immunol 10(12):12751282. https://doi.org/10.1038/ni.1793

110. Fenninger F, Han J, Stanwood SR, Nohara LL, Arora H, Choi KB, Munro L, Pfeifer CG, Shanina I, Horwitz MS, Jefferies WA (2019) Mutation of an L-type calcium channel gene leads to T lymphocyte dysfunction. Front Immunol 10:2473. https://doi.org/ 10.3389/fimmu.2019.02473

111. Matza D, Badou A, Kobayashi KS, Goldsmith-Pestana K, Masuda Y, Komuro A, McMahon-Pratt D, Marchesi VT, Flavell RA (2008) A scaffold protein, AHNAK1, is required for calcium signaling during T cell activation. Immunity 28(1):64-74. https:// doi.org/10.1016/j.immuni.2007.11.020

112. Matza D, Badou A, Klemic KG, Stein J, Govindarajulu U, Nadler MJ, Kinet JP, Peled A, Shapira OM, Kaczmarek LK, Flavell RA (2016) T cell receptor mediated calcium entry requires alternatively spliced Cav1.1 channels. PLoS ONE 11(1):e0147379. https://doi.org/10.1371/journal.pone.0147379

113. Cabral MD, Paulet PE, Robert V, Gomes B, Renoud ML, Savignac M, Leclerc C, Moreau M, Lair D, Langelot M, Magnan A, Yssel H, Mariame B, Guery JC, Pelletier L (2010) Knocking down Cav1 calcium channels implicated in Th2 cell activation prevents experimental asthma. Am J Respir Crit Care Med 181(12):1310-1317. https://doi.org/10.1164/rccm. 200907-1166OC

114. Wang H, Zhang X, Xue L, Xing J, Jouvin MH, Putney JW, Anderson MP, Trebak M, Kinet JP (2016) Low-voltage-activated Ca3.1 calcium channels shape $\mathrm{T}$ helper cell cytokine profiles. Immunity. https://doi.org/10.1016/j.immuni.2016.01.015

115. Cahalan MD, Chandy KG (2009) The functional network of ion channels in T lymphocytes. Immunol Rev 231(1):59-87. https:// doi.org/10.1111/j.1600-065X.2009.00816.X

116. Wang Y, Deng X, Mancarella S, Hendron E, Eguchi S, Soboloff J, Tang XD, Gill DL (2010) The calcium store sensor, STIM1, reciprocally controls orai and $\mathrm{CaV} 1.2$ channels. Science 330(6000):105-109. https://doi.org/10.1126/science.1191086

117. Park CY, Shcheglovitov A, Dolmetsch R (2010) The CRAC channel activator STIM1 binds and inhibits L-type voltagegated calcium channels. Science 330(6000):101-105. https:// doi.org/10.1126/science.1191027

118. Narayanan R, Dougherty KJ, Johnston D (2010) Calcium store depletion induces persistent perisomatic increases in the functional density of $\mathrm{h}$ channels in hippocampal pyramidal neurons. Neuron 68(5):921-935. https://doi.org/10.1016/j.neuron.2010. 11.033

119. Badou A, Jha MK, Matza D, Mehal WZ, Freichel M, Flockerzi V, Flavell RA (2006) Critical role for the beta regulatory subunits of Cav channels in T lymphocyte function. Proc Natl Acad Sci USA 103(42):15529-15534. https://doi.org/10.1073/ pnas.0607262103

120. Badou A, Jha MK, Matza D, Flavell RA (2013) Emerging roles of L-type voltage-gated and other calcium channels in T lymphocytes. Front Immunol 4:243. https://doi.org/10.3389/ fimmu.2013.00243

121. Kadri N, Wagner AK, Ganesan S, Karre K, Wickstrom S, Johansson MH, Hoglund P (2016) Dynamic regulation of NK cell responsiveness. Curr Top Microbiol Immunol 395:95-114. https://doi.org/10.1007/82_2015_485

122. Takanaga H, Ohtsuki S, Hosoya K, Terasaki T (2001) GAT2/ BGT-1 as a system responsible for the transport of gammaaminobutyric acid at the mouse blood-brain barrier. J Cereb Blood Flow Metab 21(10):1232-1239. https://doi.org/10.1097/ 00004647-200110000-00012
123. Bergeret M, Khrestchatisky M, Tremblay E, Bernard A, Gregoire A, Chany C (1998) GABA modulates cytotoxicity of immunocompetent cells expressing GABAA receptor subunits. Biomed Pharmacother 52(5):214-219. https://doi.org/10.1016/ S0753-3322(98)80019-X

124. Lang K, Drell TL, Niggemann B, Zanker KS, Entschladen F (2003) Neurotransmitters regulate the migration and cytotoxicity in natural killer cells. Immunol Lett 90(2-3):165-172. https://doi.org/10.1016/j.imlet.2003.09.004

125. Koga Y, Tsurumaki H, Aoki-Saito H, Sato M, Yatomi M, Takehara K, Hisada T (2019) Roles of cyclic AMP response element binding activation in the ERK $1 / 2$ and p 38 MAPK signalling pathway in central nervous system, cardiovascular system, osteoclast differentiation and mucin and cytokine production. Int J Mol Sci. https://doi.org/10.3390/ijms20061346

126. Barati MT, Scherzer J, Wu R, Rane MJ, Klein JB (2015) Cytoskeletal rearrangement and Src and PI-3K-dependent Akt activation control GABA(B)R-mediated chemotaxis. Cell Signal 27(6):1178-1185. https://doi.org/10.1016/j.cellsig.2015.02. 022

127. Bassi GS, Malvar D do C, Cunha TM, Cunha FQ, Kanashiro A (2016) Spinal GABA-B receptor modulates neutrophil recruitment to the knee joint in zymosan-induced arthritis. Naunyn Schmiedebergs Arch Pharmacol 389(8):851-861. https://doi. org/10.1007/s00210-016-1248-0

128. Yocum GT, Turner DL, Danielsson J, Barajas MB, Zhang Y, Xu D, Harrison NL, Homanics GE, Farber DL, Emala CW (2017) GABAA receptor alpha4-subunit knockout enhances lung inflammation and airway reactivity in a murine asthma model. Am J Physiol Lung Cell Mol Physiol 313(2):L406-L415. https://doi. org/10.1152/ajplung.00107.2017

129. Forkuo GS, Nieman AN, Yuan NY, Kodali R, Yu OB, Zahn NM, Jahan R, Li G, Stephen MR, Guthrie ML, Poe MM, Hartzler BD, Harris TW, Yocum GT, Emala CW, Steeber DA, Stafford DC, Cook JM, Arnold LA (2017) Alleviation of multiple asthmatic pathologic features with orally available and subtype selective GABAA receptor modulators. Mol Pharm 14(6):2088-2098. https://doi.org/10.1021/acs.molpharmaceut.7b00183

130. Dustin ML (2014) The immunological synapse. Cancer Immunol Res 2(11):1023-1033. https://doi.org/10.1158/2326-6066. CIR-14-0161

131. Tan JK, McKenzie C, Marino E, Macia L, Mackay CR (2017) Metabolite-sensing G protein-coupled receptors-facilitators of diet-related immune regulation. Annu Rev Immunol 35:371-402. https://doi.org/10.1146/annurev-immunol-051116-052235

132. Smits A, Jin Z, Elsir T, Pedder H, Nister M, Alafuzoff I, Dimberg A, Edqvist PH, Ponten F, Aronica E, Birnir B (2012) GABAA channel subunit expression in human glioma correlates with tumor histology and clinical outcome. PLoS ONE 7(5):e37041. https://doi.org/10.1371/journal.pone.0037041

133. Chavan SS, Pavlov VA, Tracey KJ (2017) Mechanisms and therapeutic relevance of neuro-immune communication. Immunity 46(6):927-942. https://doi.org/10.1016/j.immuni.2017.06.008

Publisher's Note Springer Nature remains neutral with regard to jurisdictional claims in published maps and institutional affiliations. 